\title{
Monika Krukowska
}

\section{TUNEZJA I MAROKO. OBLICZA ARABSKIEJ WIOSNY}

Na początku 2011 r. uwagę świata przykuły zmiany polityczne w Afryce Północnej. Ruch rewolucyjny zwany Arabską Wiosną objął swoim zasięgiem większość państw Maghrebu i Maszreku, doprowadzając do przejęcia władzy przez ugrupowania religijne lub przynajmniej wymuszając na dotychczasowych władzach przeprowadzenie reform politycznych. Zaskakujący sukces wyborczy ugrupowań islamskich oraz szeroki zasięg wprowadzanych zmian są zapowiedzią głębokich przeobrażeń, jakich w najbliższych latach należy oczekiwać w regionie Afryki Północnej i Bliskiego Wschodu.

Niniejsze opracowanie poświęcone jest dwóm krajom Maghrebu: Tunezji oraz Maroku. W obu państwach wprowadzane są głębokie zmiany polityczne, jednak o odmiennym charakterze. W Tunezji zmiany przebiegają w sposób gwałtowny i radykalny, głęboko ingerując w ustalony porządek społeczny. W Maroku proces przebiega spokojnie, niemal niezauważalnie, a nad jego przebiegiem czuwa król. $\mathrm{Na}$ ostateczne efekty przeobrażeń trzeba jeszcze poczekać, jednak w obu przypadkach mogą być one zaskakujące.

\section{Partie islamskie u władzy}

Kiedy w grudniu 2010 r. w miejscowości Sidi Bouzid w Tunezji młody człowiek, Mohammed Bouzaizi, dokonał samospalenia, nikt nie przypuszczał, jakie konsekwencje polityczne będzie miał ten akt desperacji. Okazało się, że nie był on osamotniony w swoich odczuciach i jest więcej takich młodych i zdesperowanych ludzi, nie tylko w Tunezji, ale także m.in. w Egipcie, Libii, Algierii i Maroku. Fala protestów i demonstracji, która rozlała się po regionie, zmiotła ze sceny politycznej prezydenta Tunezji Zine el-Abidine Ben Alego (1987-2011), a królowi Maroka Mohammedowi VI dała asumpt do wszczęcia procesu reform.

W październiku 2011 r. w Tunezji odbyły się wybory do Zgromadzenia Konstytucyjnego, które ma opracować projekt nowej ustawy zasadniczej, mającej zastąpić konstytucję z 1959 r. Wybory wygrała umiarkowanie islamska Partia Odrodzenia (Ennahda), zdobywając ponad 40\% miejsc. Kolejna partia, lewicowy Kongres 
na rzecz Republiki (Congrès pour la République - CPR) zdobyła 29 miejsc, a socjalistyczna Ettakatol (Demokratyczne Forum na rzecz Pracy i Wolności, Forum démocratique pour le travail et les libertés) zdobyła 20 miejsc. Na początku 2012 r. powstał nowy rząd koalicyjny, na którego czele stanął Hamadi Jebali (Ennahda). Prezydentem Tunezji został wybrany przez Zgromadzenie Konstytucyjne Moncef Marzouki (CPR), a przewodniczącym konstytuanty Mustapha Ben Jafar (Ettakatol).

Niemal równolegle miały miejsce wybory do Izby Reprezentantów (niższej) parlamentu Maroka (listopad 2011 r.), które wygrała umiarkowanie islamska Partia Sprawiedliwości i Rozwoju (Parti de la justice et du développement - PJD), obejmując 107 z 395 miejsc. Na drugim miejscu była monarchistyczna Partia Niepodległości (Istiqlal), otrzymując 60 mandatów, a na trzecim liberalne Narodowe Zgromadzenie Niezależnych (Rassemblement national des indépendants - RNI), zdobywając 52 miejsca. Na początku 2012 r. król wyznaczył na premiera sekretarza generalnego PJD Abdelilaha Benkiranego, który utworzył rząd koalicyjny z dwiema partiami konserwatywnymi blisko związanymi z pałacem królewskim: Istiqlalem oraz liberalnym Ruchem Ludowym (Mouvement populaire - MP), jak również niewielką Partią Rozwoju i Socjalizmu (Parti du progrès et du socialisme - PPS) ${ }^{1}$. PJD otrzymała ministerstwa sprawiedliwości, spraw zagranicznych oraz społecznych, a stronnicy króla objęli kluczowe resorty (obrony, spraw religijnych oraz rolnictwa i rybołówstwa).

I tak w dwóch państwach Maghrebu do władzy doszły ugrupowania umiarkowanie islamskie: Ennahda oraz PJD, wywodzące się wprawdzie z egipskiej partii Bracia Muzułmańscy, jednak o odmiennych cechach. Są to partie narodowe, które funkcjonowały w diametralnie różnych warunkach i niezależnie od siebie zdobyły władzę.

\section{Islam i polityka}

Aby zrozumieć obecną sytuację polityczną Maroka oraz Tunezji, należy cofnąć się do okresu dekolonizacji i pierwszych lat kształtowania się niepodległych państw. Ówcześni przywódcy: prezydent H. Bourguiba oraz król Mohammed V zdecydowali o przekształceniu Tunezji i Maroka na wzór demokracji zachodnich, z których czerpali potrzebne wzorce. Oba państwa łączy dominująca pozycja przywódcy: pre-

\footnotetext{
${ }^{1}$ Narodowe Zgromadzenie Niezależnych (RNI) zdecydowało o pozostaniu w opozycji. Moroccan king names Islamist-ledcabinet, January 3, 2012, http://af.reuters.com/article/topNews/idAFJOE80204O20120103?pageNumber=2\&virtualBrandChannel=0 [dostęp 24.10.2012].
} 
zydenta (Tunezja) oraz króla (Maroko), górującego nad sceną polityczną. Pozostałe cechy nie zostały jeszcze w pełni określone.

\subsection{Władza a islam}

Niepodległe od 1956 r. państwa wybrały różne drogi dalszego rozwoju. Tunezja zerwała z tradycją dynastyczną i powołała do życia republikę, za cel stawiając sobie szybki wzrost gospodarczy i rozwój społeczny, na wzór demokracji zachodnich. Wprawdzie w konstytucji z 1959 r. znalazł się zapis, że religią Tunezji jest islam, jednak religia traktowana była jako czynnik zacofania, niemogący sprostać oczekiwaniom nowoczesnego społeczeństwa. Ten niewielki kraj stał się jednym z prekursorów laickiego rozwoju w świecie arabskim: w 1957 r. wprowadzono kodeks statusu osobistego, w myśl którego kobiety zyskały pozycję społeczną równą mężczyznom, zakazane zostały wymuszone związki małżeńskie, ustanowiono także minimalny wiek zamążpójścia dziewcząt (17 lat). Kodeks zniósł rozwody dokonywane drogą cywilnego zerwania umowy, a kobiety i dziewczęta tunezyjskie zyskały możliwość kształcenia się, także na studiach wyższych. Zakazano m.in. publicznych modlitw, za które groziło ograniczenie wolności ${ }^{2}$. Opozycja została spacyfikowana: zlikwidowano fundacje religijne (wakfy) oraz uniwersytet teologiczny la Zitouna, będący jej głównym ośrodkiem, a sądy religijne zastąpione zostały sądami świeckimi. Wzrost popularności islamu w latach 70. zmusił prezydenta do kolejnych działań: zakazano noszenia hidżabu w miejscach publicznych, a państwo przejęło kontrolę nad szkołami koranicznymi oraz niektórymi duchownymi. Budowa nowoczesnego, laickiego społeczeństwa stała się nową formą nacjonalizmu. W nowej Tunezji nie było miejsca dla partii religijnych, których idee były sprzeczne z ideologią rządową.

Tymczasem islamiści tunezyjscy postrzegali laicki rząd jako kolejne zagrożenie dla tożsamości państw Maghrebu. Nową siłę opresyjną, która, podobnie do władz kolonialnych, chciała rządzić społeczeństwem muzułmańskim, pozbawiając je przywiązania do tradycyjnych wartości, tzw. korzeni narodu. Według islamistów po zależności kolonialnej przyszła kolejna forma zniewolenia: uzależnienie od zachodnich wartości i stylu życia. Partie islamskie niejednokrotnie doświadczyły represji ze strony władz, postrzegających je jako zagrożenie dla stabilności państwa, które należy zneutralizować. Dlatego też przywódcy nielegalnych partii islamskich byli zmu-

\footnotetext{
${ }^{2}$ M. Marks, Speaking on the Unspeakable: Blasphemy \& the Tunisian Constitution, September 4, 2012, http://carnegieendowment.org/2012/09/04/speaking-on-unspeakable-blasphemy-tunisian-constitution/ drca [dostęp 7.09.2012].
} 
szani do emigracji lub więzieni: obecny przywódca Ennahdy, Rached Ghannouchi, więziony był przez 4 lata, a za granicą spędził 22 lata.

Następca Bourguiby, Ben Ali zdecydowany był przejąć kontrolę nad religią w celu zyskania legitymizacji i jednoczesnej eliminacji islamistów z polityki. Powołano do życia Ministerstwo Spraw Religijnych, wskrzeszono uniwersytet teologiczny, a przy rządzie powstała Najwyższa Rada Islamska. Odbudowywano meczety, jednak imamów poddano kontroli, uruchomiono również nowe religijne stacje telewizyjne i radiowe. Celem prezydenta było ograniczenie wpływu zagranicznych stacji religijnych i nadanie islamowi nowego, bardziej współczesnego wizerunku33. Sukcesem Ben Alego było niewątpliwie podpisanie z islamistami Paktu Narodowego w 1988 r., w którym potwierdzone zostały prawa Republiki i kodeks statusu osobistego. Co więcej, pakt potwierdzał, że meczety powinny pozostawać pod kontrolą państwa, nie mogą jednak stać się miejscem działań politycznych ${ }^{4}$. Zachęceni współpracą islamiści usiłowali zwiększyć wpływ religii na życie codzienne Tunezyjczyków, co spotkało się z niechętnym przyjęciem społeczeństwa. Kiedy jeszcze policja odkryła plany zamachów na instytucje państwowe, opinia publiczna całkowicie odwróciła się od islamistów, a Ben Ali pozbył się zagrożenia.

Tymczasem Maroko pozostało monarchią, $\mathrm{z}$ dominującym na scenie politycznej królem (od 1957 r.), posiadającym szeroką władzę instytucjonalną oraz religijną. Ugrupowania islamskie zaczęły aktywizować się w Maroku dopiero w latach 70., stopniowo zdobywając coraz większe poparcie społeczne. Z czasem scena polityczna Maroka podzieliła się na dwa obozy: ugrupowania islamskie (islamistów) i lewicę, pomiędzy którymi był król, zapewniający równowagę systemu. Osoba władcy Maroka jest emanacją związku religii i polityki. W konstytucji Maroka z 1996 r., zgodnie z art. 42, „król, Najwyższy Przedstawiciel Narodu, Symbol jego jedności, Gwarant trwałości i ciągłości Państwa, będzie czuwał nad poszanowaniem Islamu i Konstytucji. Król jest obrońcą praw i wolności obywateli, grup społecznych i zbiorowości. Gwarantuje niepodległość Narodu i jedność terytorialną Królestwa w prawdziwych granicach”’ Król ma status Przywódcy Wiernych, a swoją władzę sprawuje poprzez ministra ds. islamu, poprzez meczety i rady gminy oraz zawii ${ }^{6}$. Król sta-

${ }^{3}$ R. Kéfi, Le Maghreb à la recherche de son islam d'Etat, http://islamiqua.canalblog.com/archives/1_islamisme_au_maghreb/index.html [dostęp 24.08.2013].

${ }^{4}$ Naissance et déclin du mouvement islamiste tunisien (2). Le debut de la fin, 22 novembre 2007, http:// islamiqua.canalblog.com/archives/2007/11/22/6981393.html\#trackbacks [dostęp 24.10.2012].

${ }^{5}$ Royaume du Maroc, la Constitution, http://mjp.univ-perp.fr/constit/ma1992.htm\#2 [dostęp 24.10.2012].

${ }^{6}$ Zawija - budynek lub zespół budynków będący siedzibą muzułmańskiego bractwa religijnego, za: Arabowie. Stownik encyklopedyczny, red. M.M. Dziekan, Wydawnictwo Naukowe PWN, Warszawa 2001, s. 364 . 
rał się dodatkowo dyskredytować działania islamistów, prowadząc własną działalność religijną: podkreślał swoją rolę obrońcy miejsc świętych islamu w Jerozolimie, zbudował meczet w Casablance ${ }^{7}$. Mohammed VI, zdając sobie sprawę z rosnącego zagrożenia ze strony ugrupowań islamskich, w 2004 r. rozpoczął reformy mające na celu ponowne przejęcie przez państwo wszelkich spraw religijnych i całkowite pozbawienie islamistów wpływów politycznych. Państwo przejęło kontrolę nad meczetami, wprowadzono także ułatwienia w procesie budowy nowych świątyń. Król wprowadził pensje i pakiety zdrowotne dla pracowników obsługujących meczety, podniósł wynagrodzenia imamów, wprowadził również kursy doszkalające duchownych ${ }^{8}$.

Zważywszy na tradycyjne przywiązanie Marokańczyków do instytucji króla, możliwość tworzenia realnej opozycji wobec władcy jest znikoma. Status monarchy osłabia upolitycznione partie islamskie ${ }^{9}$, odbierając im legitymizację do działań skierowanych przeciwko władcy. W tej sytuacji jeszcze król Hassan II (1961-1999) zezwolił na rejestrację w 1992 r. umiarkowanie islamskiej Partii Sprawiedliwości i Rozwoju (PJD), która jednak nie zyskała - jak oczekiwano - silnej pozycji politycznej.

\subsection{Arabska Wiosna w Maghrebie}

Samobójstwo M. Bouaziziego, uważane przez niektórych za przyczynę wybuchu Rewolucji Jaśminowej w Tunezji, było jedynie katalizatorem zmian. Przyczyn niezadowolenia społecznego należy upatrywać m.in. w wypaczeniu systemu politycznego, w którym władzę przejęła wąska grupa osób spokrewnionych z prezydentem Ben Alim oraz jego żoną. Rozpowszechniona korupcja, przy jednoczesnych problemach gospodarczych i społecznych (bezrobocie - zwłaszcza wśród ludzi młodych, braki mieszkaniowe etc.), doprowadziła do eskalacji nastrojów antyrządowych i w konsekwencji erupcji niezadowolenia społecznego w styczniu 2011 r. Ogólnonarodowe protesty zmusiły prezydenta do złożenia urzędu i opuszczenia kraju na początku 2011 r. Protestujących usatysfakcjonowało jednak dopiero odsunięcie od władzy Zgromadzenia Demokratyczno-Konstytucyjnego (Rassemblement constitutionnel démocratique - RCD) i powołanie na początku marca rządu pod przewodnictwem Béji Caïd Essebsiego. Nowy rząd zaplanował na lipiec wybory w celu powołania

7 R. Kéfi, Maroc: laggiornamento de l'islam, http://islamiqua.canalblog.com/archives/2010/03/15/17247816. html [dostęp 24.10.2012].

$882 \%$ z 45 tys. imamów nie ma podstawowego wykształcenia, ibidem.

9 O. Brouksy, Religion, Monarchy and the Freedom of the Press, Islamists versus Seculars. Confrontations and Dialogues in Morocco. Values Democracy Violence Freedom Education, red. Maâti Monjib, IKV Pax Christi Centre Averroes for Studies and Communication-Rabat Assemblée des Citoyens-MECAMorocco, s. 62, http://www.scribd.com/doc/46004304/Islamists-Versus-Seculars-Maati-Monjib [dostęp 2.10.2012]. 
Zgromadzenia Konstytucyjnego, jednak z przyczyn organizacyjnych odbyły się one dopiero w październiku 2011 r. Zwycięstwo Ennahdy ostatecznie przypieczętowało zmiany polityczne w Tunezji.

Także w Maroku czynnikiem sprawczym była trudna sytuacja gospodarcza, która wiosną 2011 r. doprowadziła do protestów, demonstracji i żądań reform. Trzeba podkreślić, że żadne ugrupowanie proreformatorskie nie nawoływało jednak do obalenia monarchy. Obserwując zmiany w sąsiednich krajach, król Mohammed VI rozsądnie wybrał ucieczkę do przodu, inicjując proces reform, mający przekształcić marokański system prawny. Już w marcu zapowiedział wprowadzenie szerokich zmian konstytucyjnych, które miały na celu ograniczenie władzy królewskiej na rzecz władzy parlamentarnej i rządowej, wzmocnienie wymiaru sprawiedliwości i decentralizację uprawnień. Król powołał do życia zespół ekspertów, w którego skład weszli przedstawiciele partii politycznych, związków zawodowych i grup społecznych, mający w ciągu kilku miesięcy opracować projekt nowej konstytucji ${ }^{10}$. W czerwcu $2011 \mathrm{r}$. projekt został ukończony, a 1 lipca zatwierdzony w ogólnonarodowym referendum większością 98\% głosów. Idąc za ciosem, król zorganizował przyspieszone wybory parlamentarne, które wygrała umiarkowanie islamska PJD. I oto oba kraje znalazły się w tym samym punkcie: władzę przejęły dotychczas marginalizowane ugrupowania islamskie.

Sukces wyborczy partii islamskich wywodzi się przede wszystkim z ogólnego niezadowolenia społecznego $\mathrm{z}$ dotychczasowych działań partii rządzących. Oczywiście zarówno Ennahda, jak i PJD przedstawiały swoje programy wyborcze, jednak były one raczej szkicem aniżeli konkretną propozycją zmian. PJD wygrała wybory pod hasłami walki z korupcją polityczną i finansową, a jej hasła wymierzone były w powiązania dotychczasowych elit władzy z biznesem, co zaniepokoiło rządzących. W swojej kampanii PJD podkreślała jednak, że jest partią w pełni popierającą ustrój monarchiczny i dążącą jedynie do wprowadzania stopniowych zmian w ramach istniejącego systemu. Partia prezentowała się jako siła niezagrażająca swobodom obywatelskim. Trzeba podkreślić, że PJD, działając przez lata legalnie na marokańskiej scenie politycznej, mogła uczestniczyć w życiu politycznym kraju i zdobywać doświadczenie w działalności politycznej.

Zwycięstwo Ennahdy należy przypisać jej popularności w społeczeństwie tunezyjskim: przez lata była prześladowana, a jej członkowie siedzieli w więzieniach lub przebywali na emigracji. Partia ta skupia wielu znanych polityków, a skuteczna strategia przedwyborcza jeszcze zwiększyła sukces. W kampanii wyborczej Ennahda

${ }^{10}$ S. Karam, Morocco king announces constitutional reform plan, March 10, 2011, http://af.reuters.com/ article/topNews/idAFJOE72901720110310?sp=true [dostęp 25.10.2012]. 
zapowiadała, że przywróci miejsce islamu w kulturze tunezyjskiej, odwołując się przy tym do jak najszerszego kręgu wyborców. I tak konserwatyści głosowali na Ennahdę, bo rzeczywiście oczekują większej roli religii w życiu publicznym Tunezji. Mniej konserwatywnych wyborców skusiło odwoływanie się do tradycyjnych wartości (etosu pracy i uczciwości), innych pociągnęła niechęć do rządzących elit i zapowiedź walki z korupcją. Wyborcy umiarkowani poczuli się natomiast uspokojeni brakiem nacisku na tradycyjne islamskie ograniczenia w ubiorze, m.in. zasłanianie twarzy.

W obu krajach partie islamskie popierają uboższe warstwy społeczeństwa, które nie korzystały dotąd $\mathrm{z}$ dobrodziejstw rozwoju. Elity pozostały natomiast wierne królowi (Maroko), a w Tunezji pozostają w opozycji do rządu, starając się osłabić bieg przemian.

\subsection{Reformy konstytucyjne}

Głębokie zmiany polityczne i społeczne, jakie przechodzą obecnie państwa Maghrebu, znalazły odbicie w ich systemach prawnych. Wprawdzie obie partie polityczne są ugrupowaniami o charakterze umiarkowanym, a w swoich programach wyborczych nie wspominały o najczęściej zarzucanych islamistom postulatach: oparciu prawa na szariacie (prawie muzułmańskim), wprowadzeniu ograniczeń dotyczących ubioru kobiet czy ograniczaniu roli kobiet w życiu społecznym, jednak pewne zmiany były nieuniknione.

Reformy w Maroku już właściwie zostały zakończone. Nowa konstytucja powstała w oparciu o dokładne wskazówki Mohammeda VI: król wyznaczył członków komisji, której przewodniczył doradca monarchy Abdellatif Menouni. Komisja konsultowała swoje prace $\mathrm{z}$ organem doradczym, służącym jako pośrednik pomiędzy nią a partiami politycznymi, związkami zawodowymi, stowarzyszeniami biznesowymi etc. - każdym, kto chciał uczestniczyć w procesie tworzenia nowej ustawy zasadniczej. Ostateczny efekt pracy komisji konstytucyjnej pozostawał tajemnicą niemal do chwili prezentacji projektu przez króla w przemówieniu telewizyjnym (wersja pisemna została przedstawiona dzień przed prezentacją). Mimo to większość partii politycznych, także PJD, z góry zapowiedziała poparcie konstytucji w referendum, doceniając koncyliacyjną postawę władcy w procesie opracowywania nowej ustawy zasadniczej.

Król Mohammed VI zrobił wszystko, aby nowa konstytucja została zaaprobowana przez społeczeństwo. W przemówieniu telewizyjnym król powoływał się na Koran, wzywając do poparcia projektu. Przed referendum Ministerstwo Religii nakazało imamom zachęcać do poparcia konstytucji w czasie piątkowych nabożeństw. W czasie referendum obserwatorzy donosili o kłamstwach wyborczych: nieprzyjmowaniu 
głosów "przeciw” konstytucji, zawyżonej frekwencji etc. ${ }^{11}$ Mohamed Al-Touzi, jeden z członków komitetu powołanego do opracowania nowej konstytucji, wręcz twierdzi, że projekt zaproponowany przez komisję różnił się zarówno od projektu opublikowanego w prasie, jak i od projektu finalnego przedstawionego przez króla spoleczeństwu ${ }^{12}$.

Nowa konstytucja Maroka z lipca 2011 r. w niewielkim stopniu ogranicza władzę monarchy, pozostawiając w jego wyłącznej kompetencji kwestie obronne, religijne i strategiczne, których definicja należy zresztą do kompetencji króla. Król wskazuje szefa rządu spośród członków wygranej partii politycznej, może też rozwiązać parlament po uprzedniej konsultacji z nowo utworzonym Sądem Konstytucyjnym, którego połowę członków sam powołuje ${ }^{13}$. Władca pozostaje najwyższym arbitrem w sporach między partiami politycznymi ${ }^{14}$. Wzmocnione zostało stanowisko premiera, który staje się "prezydentem rządu”; posiedzenia rządu odbywają się już bez obligatoryjnej obecności króla. Gabinet może samodzielnie podejmować decyzje odnośnie do polityki ogólnej, z wyłączeniem kwestii pozostających w domenie monarchy. Premier może rozwiązać parlament oraz nominować urzędników państwowych i pracowników przedsiębiorstw państwowych. Nowa konstytucja rozdziela uprawnienia króla jako głowy państwa i przywódcy wiernych oraz znacznie rozszerza katalog zagadnień społecznych: m.in. wprowadza równość kobiet i mężczyzn oraz ustanawia język berberyjski (Tamazight) drugim urzędowym językiem Maroka ${ }^{15}$.

W ostatecznym rozrachunku konstytucja rozszerzyła kompetencje premiera i parlamentu, kompetencje króla nie zostały jednak istotnie ograniczone. Pojawił się za to cały nowy rozdział pt. Wolności i prawa podstawowe, zawierający regulacje dotyczące m.in. statusu mężczyzn i kobiet, praw osobistych, wolności wypowiedzi, prawa do informacji, prawa do życia, mieszkania, opieki zdrowotnej etc. W czasie prac nad konstytucją najwięcej sporów wywoływał problem uznania języka berberyjskiego za drugi oficjalny język Maroka oraz kwestii, czy Maroko powinno być definiowane jako państwo islamskie. Ostatecznie w konstytucji powtórzono art. 6

${ }_{11}$ P. Silverstein, Weighing Morocco's New Constitution, July 5, 2011, http://www.merip.org/mero/ mero070511 [dostęp 25.10.2012].

12 M. Monjib, All the King's Islamists, September 20, 2012, http://carnegieendowment.org/sada/2012/09/20/ all-king-s-islamists/dvbw [dostęp 24.09.2012].

${ }^{13}$ S. Karam, Moroccos King to lose some powers but will remain, June 17, 2011, http://af.reuters.com/ article/worldNews/idAFTRE75G4M220110617 [dostęp 25.10.2012].

${ }_{14}$ M. Ottaway, The New Moroccan Constitution: Real Change or More of the Same?, June 20, 2011, http:// carnegieendowment.org/2011/06/20/new-moroccan-constitution-real-change-or-more-of-same/51 [dostęp 25.10.2012].

${ }^{15}$ Maroc: la nouvelle Constitution varéduire les pouvoirs du souverain, „Le Monde” 17.06.2011, http:// www.lemonde.fr/international/article/2011/06/17/maroc-la-nouvelle-constitution-va-reduire-les-pouvoir s-du-roi_1537583_3210.html [dostęp 25.10.2012]. 
(obecnie 3), że islam jest religią państwową, która gwarantuje swobodę kultu' ${ }^{16}$ Nad islamem czuwa król, który jest też gwarantem swobody kultu (art. 41). Osoba króla jest nietykalna, a kto złamie tę zasadę, podlega karze. W konstytucji marokańskiej brak jest odniesień do szariatu.

Polityka Mohammeda VI, jak do tej pory, okazała się skuteczna. Przejęcie inicjatywy konstytucyjnej dało królowi swobodę dokonania zmian w ograniczonym zakresie, satysfakcjonując jednak oponentów politycznych i odbierając im argumenty do dyskusji. Król okazał chęć do współpracy, co zostało docenione ${ }^{17}$. Wprowadzone zmiany nie są wprawdzie radykalne, a jednak nie spotkały się z protestem ani opozycji, ani społeczeństwa, doceniających zmiany znacznie zbliżające ustawę zasadniczą Maroka do konstytucji demokratycznych państw zachodnich. Wykorzystanie możliwości, jakie daje nowa konstytucja, będzie zależało także od partii politycznych i samych obywateli. Warto podkreślić, że od przyjęcia nowej ustawy zasadniczej minęło już sporo czasu, a Maroko pozostaje oazą spokoju na tle innych państw regionu.

Głębsze zmiany mają tymczasem miejsce w Tunezji. Zgromadzenie Konstytucyjne wciąż kontynuuje prace nad projektem nowej ustawy zasadniczej, mającej być kamieniem węgielnym drugiej republiki. Głosowanie nad nową konstytucją planowane było na wiosnę 2013 r., jednak konieczność negocjacji wielu kwestii spornych sprawiła, że przedłużono prace do połowy 2013 r. Długotrwały jest także sam proces przyjmowania ustawy zasadniczej: każdy artykuł ma być głosowany osobno, po czym odbędzie się głosowanie nad całością, która ma zostać przyjęta większością dwóch trzecich członków Zgromadzenia Konstytucyjnego ${ }^{18}$.

Wciąż nie jest znany ostateczny projekt ustawy zasadniczej. W prasie tunezyjskiej i międzynarodowej toczy się dyskusja na temat kolejnych drażliwych zagadnień o charakterze społecznym, które mają być wprowadzone przez nową konstytucję i które wywołują dużo emocji: oparcie prawa na szariacie i wiążące się z tym ograniczenia obyczajowe, status kobiet czy kary za bluźnierstwo. Kontrowersyjne propozycje zgłaszane są przez rządzącą Ennahdę, jednak podlegają negocjacjom koalicyjnym. Pod naciskiem opinii publicznej zarówno tunezyjskiej, jak i międzynarodowej Zgromadzenie - jak do tej pory - rezygnowało z wprowadzenia większego wpływu islamu na życie polityczne i społeczne w Tunezji.

\footnotetext{
${ }^{16}$ Royaume du Maroc, la Constitution, op.cit., s. 5.

${ }_{17}$ Dotychczasowe nowelizacje konstytucji wprowadzane przez ojca Mohammeda VI, króla Hassana II, były zmianami kosmetycznymi w prawdziwym tego słowa znaczeniu.

18 Tunisie: accord sur la Constitution et élections générales le 23 juin, „Le Monde” 14.10.2012, http://www. lemonde.fr/tunisie/article/2012/10/14/tunisie-accord-sur-la-constitution-des-elections-generales-le-23juin_1775271_1466522.html [dostęp 25.10.2012].
} 
Od początku gorące dyskusje wywoływała zwłaszcza kwestia oparcia nowej konstytucji na szariacie, co oznaczałoby odejście od zasady laickości państwa. Debatę dodatkowo podgrzewały nieopatrzne wypowiedzi polityków rządzącej Ennahdy, jak słowa ówczesnego premiera H. Jebali z listopada 2011 r. o „szóstym kalifacie”. Szykująca się do koalicji partia Ettakatol wstrzymała wówczas rozmowy koalicyjne, stwierdzając, że chce budować drugą republikę, a nie szósty kalifat ${ }^{19}$. Prawdopodobnie premier miał na myśli tylko świetlaną przyszłość Tunezji, jednak świecka (przeciwna islamistom) część społeczeństwa oraz opinia międzynarodowa odebrały to jako zapowiedź głębokich zmian. Podobne przykłady niefortunnych wypowiedzi można mnożyć, wszystkie były przyczyną wzrostu niepokoju wśród przeciwników islamizacji kraju i eksplozji radości w ugrupowaniach bardziej radykalnych.

Ostatecznie, po miesiącach niepewności, w marcu 2012 r. koalicja zdecydowała o nieopieraniu nowej konstytucji Tunezji na szariacie ${ }^{20}$. Artykuł 1 nowej ustawy zasadniczej przyjmie zatem brzmienie art. 1 konstytucji z 1959 r.: „Tunezja jest wolnym, suwerennym i niezależnym państwem. Jej religią jest islam, językiem język arabski, a ustrojem Republika”. Przywódca Ennahdy, R. Ghannouchi, uzasadnił tę decyzję w następujący sposób: „konstytucje, które trwają, są oparte na konsensusie. W tej chwili szariat nie jest konsensusem dla Tunezyjczyków, a islam jest; zatem nowa konstytucja oparta będzie na islamie"21. W innym wywiadzie podkreślał, że Ennahda chce uniknąć podziału społeczeństwa tunezyjskiego na dwa wrogie sobie obozy ideologiczne. Dodał, że jego zdaniem 90\% prawa tunezyjskiego i tak jest zgodne z prawem szariatu ${ }^{22}$. Wypowiedzi przywódcy partii rządzącej z jednaj strony uspokajają, z drugiej każą podejrzewać, że być może w przyszłości Ennahda podejmie jednak próbę wprowadzenia szariatu.

Innym zagadnieniem jest problem bluźnierstwa, które do tej pory nie było regulowane w ustawie zasadniczej z 1959 r. Wprowadzenie do konstytucji proponowanego przez Ennahdę zapisu karzącego za bluźnierstwo byłoby istotnym ograniczeniem wolności wypowiedzi i prawa mediów, dając ugrupowaniom radykalnym

19 J. Mitchell, Tunisia's Islamists hail arrival of the 'sixth caliphate', November 16, 2011, http://www.telegraph. co.uk/news/worldnews/africaandindianocean/tunisia/8894858/Tunisias-Islamists-hail-arrival-of-the-sixth-caliphate.html [dostęp 1.10.2012].

${ }^{20}$ Ces islamistes qui disent non à la charia, „Le Monde” 27.03.2012, http://www.lemonde.fr/tunisie/article/2012/03/27/ces-islamistes-qui-disent-non-a-la-charia_1676283_1466522.html [dostęp 25.10.2012].

${ }^{21}$ Tunisia's Islamists say constitution will not be based on Sharia, March 27, 2012, http://www.demdigest. net/blog/2012/03/tunisias-constitution-will-not-be-based-on-sharia/Tunisia's Islamists say constitution will not be based on Sharia [dostęp 25.10.2012].

22 B. Ben Bouazza, Islam won't be basis of new Tunisian constitution, Associated PressTunis, March 26, 2012, http://www.breitbart.com/Big-Peace/2012/03/26/Islam-wont-be-basis-of-new-Tunisian-constitution [dostęp 10.10.2012]. 
niebezpieczny instrument do walki o islamizację kraju. Dopiero w połowie października 2012 r. przewodniczący Zgromadzenia Konstytucyjnego Mustafa Ben Jaafar oficjalnie potwierdził usunięcie zapisów o bluźnierstwie z projektu konstytucji²3.

Problematyczna okazała się także kwestia kształtu nowego systemu politycznego Tunezji, nad którą jeszcze do niedawna nie było niemal dyskusji. Do tej pory nie zdecydowano, czy wybrać system prezydencki, czy może wzmocnić rolę rządu. Brak zgody także odnośnie do takich kwestii, jak równowaga między elementami systemu, powołanie do życia sądu konstytucyjnego, procedura wprowadzania poprawek, reforma systemu bezpieczeństwa czy decentralizacja władzy ${ }^{24}$. Zwłaszcza partie koalicyjne długo nie mogły osiągnąć w tej kwestii konsensusu: Ennahda proponowała system parlamentarny, chcąc oddać władzę w ręce społeczeństwa i ograniczyć rolę egzekutywy, podczas gdy pozostałe partie koalicyjne optowały za systemem prezydenckim. Ostatecznie porozumienie osiągnięto w październiku 2012 r. Tunezja ma mieć system mieszany, w którym prezydent będzie wybierany w wyborach powszechnych, a premier przez parlament. Niezmiernie ważnym problemem jest zachowanie równowagi pomiędzy egzekutywą a legislatywą, innymi słowy, zabezpieczenie przed przejęciem władzy przez prezydenta, jak to miało miejsce w pierwszej republice. Dla regionów zagadnieniem priorytetowym pozostaje natomiast decentralizacja władzy, która ma mieć pozytywny wpływ na walkę z korupcją i równomierny rozwój regionów nadmorskich i wewnętrznych.

Dotychczasowe decyzje Zgromadzenia Konstytucyjnego Tunezji tylko częściowo uspokoiły zwolenników państwa świeckiego, którzy wciąż obawiają się nowych pomysłów ugrupowań islamskich. Dopóki konstytucja nie zostanie ostatecznie przyjęta, dopóty możliwe będą zmiany, a naciski islamistów są coraz bardziej gwałtowne. Pewną nadzieją napełniają działania nowego premiera, który doprowadził do podjęcia dialogu między rządem a organizacjami pozarządowymi, opozycją i grupami społecznymi na temat projektów rozwiązań, jakie zawarte mają być w nowej konstytucji ${ }^{25}$.

Mimo że obie ustawy zasadnicze: Maroka i Tunezji wprowadzają istotne zmiany ustrojowe i społeczne, spotykają się z diametralnie różnym przyjęciem opinii publicznej. W Maroku debata dotyczy głównie relacji pomiędzy władcą a egzekutywą,

23 A. Lambroschini, No blasphemy clause in new Tunisia constitution: speaker, October 12, 2012, http:// www.google.com/hostednews/afp/article/ALeqM5jMUXZeppQ7RVPPDjq-PdVM9FXlyw?docId=CNG.26e5a2027ea5d8023b27181d36bd2cef.a1 [dostęp 25.10.2012].

${ }^{24}$ D. Pickard, The Current Status of Constitution Making in Tunisia, „Commentary” April 19, 2012, http://carnegieendowment.org/2012/04/19/current-status-of-constitution-making-in-tunisia [dostęp 25.10.2012].

${ }_{25}$ M. Kerrou, Pulling Tunisia back from the brink, August 13, 2013, http://carnegie-mec.org/2013/08/13/ pulling-tunisia-back-from-brink/gi7j [dostęp 30.08.2013]. 
poświęcając niewiele uwagi kwestiom społecznym. Tymczasem w Tunezji żarliwa dyskusja skupia się na problematyce społecznej: na prawach kobiet, mniejszości religijnych etc., niemal w ogóle nie dotykając problematyki politycznej.

\subsection{Praktyka}

Kiedy opadły emocje, a sytuacja w krajach Maghrebu się ustabilizowała, partie islamskie przystąpiły do sprawowania władzy. Współpraca ugrupowań islamskich z innymi partiami politycznymi oraz królem układa się różnie, na pewno jednak nie jest łatwa.

W ostatnich miesiącach często dochodzi do zadrażnień pomiędzy rządem i królem Mohammedem VI, a problemy wynikają przede wszystkim z natury nowej konstytucji - licznych niejasności pozwalających dowolnie interpretować zapisy ustawy zasadniczej. I tak, realizując obietnice wyborcze, PJD wszczęła postępowanie przeciwko dawnemu ministrowi finansów Salaheddine`owi Mezouarowi i obecnemu ministrowi skarbu Noureddine 'owi Bensoudzie, oskarżonym o korupcję. Stosunki między PJD a pałacem znacznie się wówczas pogorszyły, a król wszczął własną walkę z korupcją, skierowaną przede wszystkim przeciwko członkom PJD. Kolejny konflikt wybuchł w marcu 2012 r., kiedy minister komunikacji Mustafa El Khalfi zaczął wprowadzać obiecane przed wyborami reformy mediów, niezgodne z królewską wizją polityki medialnej. Także w 2012 r. młody działacz PJD Abdelali Hamieddine zarzucił królowi, że jego kompetencje kolidują z kompetencjami premiera, są więc niezgodne z konstytucją. Zarzuty Hamieddine’a wywołała decyzja króla o wszczęciu postępowania przeciw policjantom i celnikom z Tangeru i aresztowania 130 urzędników rządowych oskarżonych o korupcję i złe traktowanie imigrantów. W odpowiedzi na zarzuty minister spraw wewnętrznych, za poduszczeniem pałacu królewskiego, nie wydał zgody na wiec PJD, na którym miał przemawiać premier i pierwszy sekretarz PJD A. Benkirane ${ }^{26}$.

Także w Tunezji utrzymanie koalicji wymaga wielu negocjacji i kompromisów. W czerwcu 2012 r. rząd Tunezji zgodził się na ekstradycję byłego premiera Libii Al Baghdadiego Ali al-Mahmoudiego, co spowodowało poważny kryzys polityczny. $\mathrm{Na}$ ekstradycję nie chciał zgodzić się prezydent M. Marzouki, który obawiał się, że proces będzie niesprawiedliwy, natomiast rząd stał na stanowisku, że do ekstradycji nie jest potrzebna zgoda prezydenta. W rezultacie w parlamencie głosowano nad wotum zaufania dla rządu, którego przegłosowanie zmieniłoby w zasadniczy sposób charakter transformacji Tunezji: z łagodnej na znacznie bardziej gwałtowną.

${ }^{26}$ M. Monjib, op.cit. 
Decydujący może okazać się ostatni kryzys wywołany kolejnym już zabójstwem przez islamistów nieprzychylnego im polityka. Wybuchły kolejne zamieszki, opozycja wezwała rząd do ustąpienia, a konstytuanta ogłosiła zawieszenie prac. W rezultacie przywódca Ennahdy R. Ghannouchi zaproponował rozważenie przyspieszenia wyborów parlamentarnych zaplanowanych na koniec 2013 r. ${ }^{27}$

Wyznacznikiem dojrzałości politycznej partii religijnych jest podejście do wyborów parlamentarnych. Obie partie odrzuciły możliwość zastosowania siły w celu zdobycia władzy i zapewniają, że kolejne wybory w Tunezji i Maroku odbędą się zgodnie z literą prawa. Aby udowodnić swą determinację, Ennahda swoje działania przedstawia w perspektywie krótkoterminowej (do wyborów) i długoterminowej (po ewentualnej reelekcji). A jednak prace konstytuanty wciąż nie zostały zakończone i tak naprawdę nie wiadomo, kiedy wybory miałyby się odbyć. Z kolei wybory w Maroku odbywają się regularnie, tak więc raczej nie ma z tej strony zagrożenia. Niejasna jest natomiast polityka PJD, która straciła miejsce w parlamencie w wyborach z 2007 r., i która prawdopodobnie nie będzie chciała powtórzyć klęski.

Dojście do władzy ugrupowań islamskich nie tylko czyni scenę polityczną Maroka i Tunezji bardziej pluralistyczną i zróżnicowaną. Może także przyczynić się do swego rodzaju cywilizowania zbyt radykalnych trendów religijnych. Dopuszczenie islamistów do władzy natychmiast poprawiło sytuację polityczną w obu krajach. Społeczność Maroka i Tunezji usatysfakcjonowały nowe twarze w polityce, twarze ludzi nie tylko nieskalanych władzą, ale wręcz do tej pory pozostających w wyraźnej opozycji do sił rządzących. Efekt „nowości” nie tylko wyciszył niepokoje społeczne, dał także rządowi czas na okrzepnięcie w nowej sytuacji. Decydując o tworzeniu rządu, islamiści wzięli na siebie odpowiedzialność za kraj, za społeczeństwo, za przyszłe wydarzenia będące konsekwencją ich decyzji, ale także decyzji ich poprzedników. Już nie będą mogli używać argumentu „to nie my”. W rezultacie kolejne wybory nie będą już tak łatwe do wygrania. Aby zwyciężyć, Ennahda i PJD będą musiały wykazać swoją skuteczność w działaniu, w realizacji obietnic wyborczych, co nie jest łatwym zadaniem. Co więcej, należy przypuszczać, że z biegiem czasu partie religijne jeszcze bardziej złagodzą swoje poglądy. Władza i odpowiedzialność zmuszają bowiem do kompromisów.

Dalsze działania zarówno Ennahdy, jak i PJD będą prawdopodobnie skupiały się na uspokajaniu nastrojów społecznych i koniecznych reformach gospodarczych. Nośne hasła polityczne dobre są na okres kampanii wyborczych, często jednak okazują się zbyt trudne lub wręcz niemożliwe do realizacji. Dlatego wydaje się,

27 T. Heneghan, Fledgling democracy could survive in crisis-hit Tunisia, August 29, 2013, http://www.reuters.com/article/2013/08/29/us-tunisia-crisis-democracy-idUSBRE97S0S720130829 [dostęp 30.08.2013]. 
że najbliższe miesiące i lata zweryfikują programy polityczne, a ostateczna weryfikacja nastąpi podczas kolejnych wyborów parlamentarnych ${ }^{28}$.

\section{Islam i społeczeństwo}

Największe zmiany wywołane rewolucją zachodzą w społeczeństwach krajów Maghrebu. Dojście do władzy partii islamskich na pierwszy plan wysunęło nowe zagadnienia: związku pomiędzy religią i państwem, statusu kobiet i ich roli w życiu społecznym i politycznym krajów, problemy wolności osobistych czy swobody uprawiania sztuki. Społeczeństwa Tunezji i Maroka wyraźnie podzieliły się na dwa przeciwne obozy: zwolenników większej roli islamu (islamistów) oraz ich przeciwników (świeckich). O ile jednak debata w Tunezji jest rzeczywiście gwałtowna, o tyle w Maroku kwestie społeczne nie wywołują tylu kontrowersji.

\subsection{Status kobiet}

Ze względu na fakt, że kobiety w Tunezji od dawna cieszą się prawami niespotykanymi w innych kraju arabskich, walka pomiędzy islamistami a ich przeciwnikami odbywa się o zachowanie dotychczasowego status quo. Nie jest to zadanie łatwe ze względu na nieustanne próby podejmowane przez Ennahdę oraz ugrupowania radykalne wprowadzenia bardziej rygorystycznych odwołań do szariatu. Społeczeństwo tunezyjskie korzysta obecnie ze zniesienia ograniczeń nałożonych przez poprzedniego prezydenta, co oznacza, że coraz częściej na ulicach Tunisu spotyka się kobiety w całości zakryte hidżabem, nie wyłączając rękawiczek, a mężczyźni coraz częściej noszą brody. O ile demonstrowanie przywiązania do wiary nie przeszkadza większości społeczeństwa, o tyle przeciwnicy islamizacji nie chcą zgodzić się na narzucenie zasad islamu całemu społeczeństwu. Ennahda wprawdzie oficjalnie nie narzuca kodu ubioru kobietom, nie ukrywa jednak, że w pełni popiera wymogi islamu.

Kolejna dyskusja publiczna dotyczyła statusu kobiet. W sierpniu 2012 r. jedna z komisji Zgromadzenia Konstytucyjnego przyjęła artykuł przyszłej ustawy zasadniczej niemówiący o równości płci, a jedynie o komplementarności kobiety wobec mężczyzny. Organizacje feministyczne wszczęły alarm, jednak przedstawiciele Ennahdy

28 Tunisie: accord pour des élections législatives et présidentielle le 23 juin, 14/10/2012, http://www.jeuneafrique.com/Article/DEPAFP20121014102215/tunisie-elections-legislatives-ennahdha-presidentielle-tunisiennetunisie-accord-pour-des-elections-legislatives-et-presidentielle-le-23-juin.html [dostęp 25.10.2012]. 
stwierdzili, że - ich zdaniem - komplementarność nie wyklucza równości i uważają całą sprawę za przesadzoną ${ }^{29}$.

W krajach Maghrebu wciąż aktualna jest tradycyjna wizja roli kobiety w społeczeństwie muzułmańskim: praca jest traktowana jako zło konieczne, a naczelnym zadaniem kobiety jest dbanie o dom. Ennahda deklarowała poparcie równego dostępu do pracy i wykształcenia dla kobiet i mężczyzn, jak również dla udziału kobiet w życiu politycznym kraju, oferując miejsca na swoich listach wyborczych. Z 49 mandatów wywalczonych przez kobiety aż 42 należą do posłanek Ennahdy. Partia podkreśla jednak, że nie zamierza rezygnować z poligamii ani zmieniać zasad dziedziczenia $^{30}$, ponieważ regulacje te „są skrojone dokładnie na potrzeby Tunezji”, jak powiedział obecny premier, wówczas minister spraw wewnętrznych Ali Laray$\mathrm{edh}^{31}$.

Inaczej w Maroku, gdzie proces odchodzenia od patriarchalnej wizji związków damsko-męskich nie jest tak zaawansowany. Zmianom patronuje król, rozszerzając prawa kobiet czasami niejako wbrew oczekiwaniom samego społeczeństwa ${ }^{32}$. Stosunkowo niedawno, w 2004 r. zmieniony został kodeks rodzinny Moudawana: kobiety zyskały prawo do wystąpienia o rozwód, mogą same decydować o wstąpieniu w związek małżeński, zrównane zostały prawa męża i żony ${ }^{33}$. Zmiany te spotkały się ze zrozumiałym sprzeciwem islamistów, nie odwiodły jednak króla od dalszych reform. Nowa konstytucja poszła o krok dalej: w art. 19 podkreśla równość kobiet i mężczyzn pod względem praw i wolności o charakterze cywilnym, politycznym, gospodarczym, społecznym, kulturalnym i środowiskowym. Konstytucja zawiera także postanowienia o równym dostępie do urzędów wybieralnych ${ }^{34}$.

Proces regulacji kwestii społecznych wywołuje w Tunezji dużo emocji. Często odbywają się demonstracje, które są brutalnie rozpraszane przez siły porządkowe.

${ }^{29}$ Ch. Boitiaux, „Complémentarite”” contre „égalité” des sexes, la polémique enflé en Tunisie, http:// www.france 24.com/fr/20120808-tunisie-droits-femmes-feminisme-complementarite-contre-egalite-sexes-projet-loi-polemique-constitution [dostęp 25.10.2012].

$30 \mathrm{~W}$ prawie islamskim kobiety dziedziczą połowę tego, co dziedziczy mężczyzna.

31 F.A. Gerges, The New Islamists: Pluralism and Minorities?, http://blogs.lse.ac.uk/ideas/2012/05/ the-new-islamists-pluralism-and-minorities/ [dostęp 25.10.2012].

32 W sondażu przeprowadzonym w 2009 r. aż 49\% Marokańczyków uważa, że reforma kodeksu rodzinnego dała kobietom zbyt dużo praw, 30\% jest zdania, że już nie należy zmieniać kodeksu, a tylko $16 \%$ pragnie więcej zmian, http://www.google.pl/url?sa=t\&rct=j\&q=maroc proc.20droit proc.20des proc.20femmes proc.20sondage proc.20roi\&source=web\&cd=1\&ved=0CB8QFjAA\&url=http proc.3A proc.2F proc.2Fmaghreb-moyen-orient.jeuneafrique.com proc.2Fmohammed-vi-sondage-bilan-roi-maroc. html\&ei=_iiRUNa5MtDUsgbfjGoCg\&usg=AFQjCNFBpr_tW7L15TMyCbBPUfbMteMtTg [dostęp 25.10.2012].

${ }^{33}$ L. El Bachiri, Place de la femme dans le droit musulman à travers l'exemple du code de la famille du Maroc: la moudawana entre tradition et modernité, „Les islams, reliures” no. 26, Printemps-Eté 2011, Belgique.

34 Royaume du Maroc, la Constitution, op.cit., s. 11. 
Pojawiają się nawet oskarżenia o chęć zagarnięcia władzy i upodobnienie się do reżimu Ben Alego w niedopuszczaniu do krytyki. Natomiast społeczeństwo Maroka $\mathrm{z}$ większym spokojem podchodzi do procesu reform, nie ma gwałtownych manifestacji ani potyczek w prasie.

\subsection{Religia i ugrupowania salafickie}

Miejsce religii w życiu politycznym kraju jest przedmiotem żywych dyskusji w Afryce Północnej. Jeden z liderów PJD, Abdel Ilah Bin Kiran, wkrótce po zwycięstwie wyborczym podkreślił, że miejsce religii jest w meczetach, a jego partia nie będzie ingerować w życie osobiste obywateli Maroka. Religia pozostaje jednak punktem odniesienia dla polityków, którzy usiłują pogodzić wartości religijne ze świeckimi (demokratycznymi). O ile politycy przyzwyczajeni są do koniecznych kompromisów, o tyle ich wyborcy już niekoniecznie. Stąd ryzyko, że - w obawie przed kolejnymi wyborami - politycy uważani za umiarkowanych będą zaostrzać swoje poglądy, by schlebiać gustom bardziej radykalnych wyborców.

Partie islamskie cieszą się obecnie ogromnym poparciem społecznym we wszystkich państwach Maghrebu. Przyczyn ich popularności należy szukać m.in. w jednorodności religijnej Maroka czy Tunezji, gdzie odpowiednio 99\% i 98\% społeczeństwa to muzułmanie. W Maroku siłę religii wzmacnia dodatkowo pozycja króla, który nosi tytuł amir al-mouminin, czyli „przywódca wiernych” Atutem tunezyjskich partii politycznych jest fakt, iż jeszcze do niedawna były one zakazane ${ }^{35}$ i dyskryminowane. Ugrupowania religijne, z których wywodzą się partie islamskie, znane są ze swojej działalności społecznej i prac dobroczynnych: w ubogich regionach Afryki prowadzą szkoły, przytułki, lecznice. W większości państw Maghrebu poziom opieki społecznej jest wysoce niezadowalający, stąd inicjatywy prospołeczne były widoczne i wysoko cenione.

Wyniesione na fali niezadowolenia społecznego, Ennahda i PJD rozpoczęły trudny proces reform. Działania znacznie utrudniają radykalne formacje islamskie, m.in. ugrupowania salafickie, do których należą ultrakonserwatywni muzułmanie nawołujący do głębokich zmian politycznych i społecznych opartych na religii. Odrzucają oni zasady nowoczesnego społeczeństwa, a jedynym źródłem prawa jest

\footnotetext{
${ }^{35}$ Konserwatywne partie religijne mogą legalnie działać w Maroku od 1992 r. W Tunezji Ben Alego ugrupowania islamskie mogą działać legalnie dopiero od niedawna: w maju 2012 r. zalegalizowana została partia Islah Front, a w lipcu 2012 r. rząd Tunezji zgodził się na legalizację radykalnego ugrupowania międzynarodowego Hizb al-Tahrir: walczącego o utworzenie Kalifatu i zajmującego się nawracaniem niewiernych. Hizb al-Tahrir nie popiera demokracji, jest zakazane w wielu krajach; T. Amara, Tunisia legalises second hardline Islamist group, July 18, 2012, http://af.reuters.com/article/tunisiaNews/idAFL6E8IIEH320120718?sp=true [dostęp 24.09.2012].
} 
dla nich Koran. Początkowo salafici nie byli traktowani jako zagrożenie, ponieważ stanowią niewielką grupę popieraną przez $15-20 \%$ ludności Tunezji. Jest to więc mniejszość, ale mniejszość głośna, aktywnie i bezpardonowo walcząca o własne przekonania. Większość mieszkańców Tunezji pozostawała w przekonaniu, że salafici nie są w stanie zagrozić procesowi demokratyzacji, tym bardziej że Ennahda odżegnywała się od współpracy z nimi. Ostatnie miesiące pokazały jednak, że byli w błędzie. Wykorzystując brak zdecydowanej reakcji ze strony rządu oraz sił policyjnych, ugrupowania salafickie mnożą demonstracje, organizują protesty, zwykle o gwałtownym charakterze, a także zakłócają pokojowe demonstracje przeciwników wprowadzenia szariatu. Ich celami są artyści lub zwykli obywatele. Przykłady można mnożyć: w styczniu 2012 r. salafici opanowali miejscowość Sejnane, gdzie zaprowadzili porządek koraniczny: zakazali oglądania telewizji, sprzedaży używek, kobietom nakazali noszenie hidżabu, były przypadki poważnych uszkodzeń ciała niepokornych $^{36}$. Miejscowa policja nie podjęła jednak interwencji. We wrześniu 2012 r. salafici włamali się do ambasady USA w Tunisie, a w miejscowości Sidi Bouzid zdewastowali Horchani hotel - jedyne miejsce w mieście, gdzie można było pić alkohol. Salafici atakują kobiety za nienoszenie nakryć głowy, dziennikarzy za nieprzychylne komentarze w prasie, a artystom uniemożliwiają pracę twórczą ${ }^{37}$. Miejscami szczególnie ostrych sporów stały się uniwersytety, na których atakowani są wykładowcy i studiujące dziewczęta.

Strategia salafitów jest bardzo prosta i jednocześnie skuteczna. Zwykle nie łamią oni prawa, a jedynie wymuszają na innych postępowanie zgodne z zasadami szariatu. Przykładem może być odwołanie w sierpniu 2012 r. występu śpiewaka Lotfiego Bouchnaka, któremu na festiwalu muzycznym w Kairuanie mieli akompaniować artyści irańscy (szyici). Salafici (sunnici) uznali, że występ szyitów byłby zamachem na świętość czwartego miasta świętego islamu, jakim jest Kairuan. Zastraszeni muzycy zrezygnowali z występu ${ }^{38}$. Jeżeli jednak łagodne metody nie skutkują, salafici nie cofają się przed użyciem przemocy, czego doświadczyło dwóch niechętnych im polityków, zamordowanych w lutym i lipcu 2013 r.

36 A. Thedrel, À Sejnane, les salafistes tunisiens font la loi, 19/01/2012, http://www.lefigaro.fr/ mon-figaro/2012/01/19/10001-20120119ARTFIG00678--sejnane-les-salafistes-tunisiens-font-la-loi.php [dostęp 25.10.2012].

${ }^{37}$ N. Meo, Aggressive Salafist Islamists threaten Tunisia's dream of freedom, September 22, 2012, http:// www.telegraph.co.uk/news/worldnews/africaandindianocean/tunisia/9559867/Aggressive-Salafist-Islamists-threaten-Tunisias-dream-of-freedom.html [dostęp 1.10.2012].

${ }^{38}$ T. Cavaillès, Les salafistes tunisiens imposent leur ordre moral, 20/08/2012, http://www.lefigaro.fr/ international/2012/08/19/01003-20120819ARTFIG00189-les-salafistes-tunisiens-imposent-leur-ordre-moral.php [dostęp 25.10.2012]. 
Nośne hasła salafitów podchwytywane są głównie przez bezrobotną młodzież, rozczarowaną ciągłym brakiem perspektyw oraz niechętnych zmianom ludzi starszych. Większość społeczeństwa Tunezji oburza brak interwencji sił porządkowych i wyraźnego potępienia działań salafitów przez rząd i Ennahdę. Ludzie młodzi, którzy opowiadają się za zachodnim stylem życia, jak również przeciwnicy ugrupowań islamskich narzekają, że rząd tunezyjski nie traktuje islamistów poważnie, jako rzeczywiste zagrożenie swobód obywatelskich. Niezdecydowana postawa rządu wykorzystywana jest $z$ kolei przez islamistów, coraz brutalniej wymuszających swoje racje. Niektórzy snują nawet przypuszczenia, że Ennahda w rzeczywistości wspiera salafitów, bądź ze względu na wspólne korzenie religijne, bądź też posługuje się nimi dla podkreślenia swojej umiarkowanej pozycji politycznej3. ${ }^{39}$ Co więcej, zdarzały się sytuacje, kiedy demonstracje przeciwników islamizacji w Tunezji były pacyfikowane nie tylko przez policję, ale także przez bojówki aktywistów partii islamskich ${ }^{40}$, co było odebrane jako współdziałanie rządu z radykałami.

Ennahda znalazła się w trudnej sytuacji. Legalizacja partii radykalnych pozwala wciągnąć islamistów do polityki i uciąć tym samym zarzuty z ich strony. Jednocześnie jednak islamiści zyskali status partii politycznej i mają szerszy dostęp do wyborców. Jako partia islamska Ennahda popiera, przynajmniej częściowo, zmiany, o które apelują salafici. Są to jednak zmiany o zbyt radykalnym charakterze, które całkowicie zmieniłyby oblicze Tunezji i byłyby nie do przyjęcia dla większości społeczeństwa tunezyjskiego. Z drugiej strony Ennahda musi odpierać ataki świeckich, którzy oskarżają ją o zbyt tolerancyjne podejście do salafitów, o pobłażliwe traktowanie demonstracji islamskich i zbyt duże kary dla demonstrantów antyislamskich (używanie siły w pacyfikowaniu demonstracji uznawanych za nielegalne). W odpowiedzi na zarzuty ówczesny minister spraw wewnętrznych Tunezji Ali Larayedh zapowiedział wojnę z salafitami, którzy uciekają się do przemocy i zagrażają społeczeństwu tunezyjskiemu ${ }^{41}$. Zaostrzający się spór próbował oddalić przewodniczący Ennahdy, R. Ghannouchi, który wykluczył użycie siły i zdecydowanie opowiedział się za dialogiem. Co więcej, R. Ghannouchi zapowiedział, że rząd Tunezji zamierza zmienić swoją politykę wobec islamistów, którzy są „zagrożeniem dla Ennahdy, swobód obywatelskich i publicznego bezpieczeństwa Tunezji”"42.

\footnotetext{
${ }^{39}$ Ibidem.

${ }^{40}$ D. Britain, Islamists of Tunisia: Reconciling national contradictions, April 13, 2012, http://blogs.lse. ac.uk/ideas/2012/04/islamists-of-tunisia-reconciling-national-contradictions/ [dostęp 25.10.2012].

${ }^{41}$ Ibidem.

${ }^{42}$ Rachid Ghannouchi veut „serrer la vis” contre les salafistes, „Le Monde” 21.09.2012, http://www.lemonde. fr/societe/video/2012/09/21/rachid-ghannouchi-veut-serrer-la-vis-contre-les-salafistes_1763791_3224.htm1 ? $x \operatorname{tmc}=$ tunisie $\& x t c r=5$ [dostęp 1.10.2012].
} 
Polityka rządu nie zadowala jednak żadnej ze stron. Większość mieszkańców nie chce zmiany dotychczasowego świeckiego charakteru państwa i z niepokojem obserwuje rosnącą aktywność ugrupowań ultrakonserwatywnych, wzywających do odnowy moralnej i sprawiedliwości społecznej. Islamiści otwarcie dążą do budowy nowego społeczeństwa, opartego na zasadach zawartych w Koranie. Przeciwnicy islamizacji kraju bacznie obserwują działania rządu i Ennahdy, nieustannie krytykując wszelkie przejawy nadużycia władzy lub bierności ze strony rządu. Ich determinacja wzrasta, a krytyka rządu staje się coraz bardziej gwałtowna z obawy, że ich protest okaże się nieskuteczny i rząd ulegnie naciskom ugrupowań islamskich.

W Maroku nie wystąpił dotąd problem z ugrupowaniami radykalnymi. Salafici marokańscy są podzieleni i nie są jeszcze gotowi do wejścia na scenę polityczną, a ich działania ograniczają się do edukacji i nawracania ${ }^{43}$. Wydaje się jednak, że ugrupowania religijne są istotnym zagrożeniem dla dalszego rozwoju Tunezji i Maroka. Wprowadzenie postulowanych przez nie zmian miałoby katastrofalne skutki społeczne: ograniczenie dostępu do edukacji dla płci żeńskiej cofnęłoby rozwój społeczny Tunezji o kilka dekad, bezpowrotnie zniszczony byłby zagraniczny wizerunek Tunezji jako państwa pozytywnie wyróżniającego się na tle innych krajów regionu. Z kolei nieustępliwa polityka rządu może skutkować wzrostem agresji i destabilizacją sceny politycznej.

\section{Islam i gospodarka}

Pierwotną przyczyną rozbudzenia politycznego krajów Maghrebu nie była walka o miejsce religii w życiu politycznym i gospodarczym kraju, ale walka o godne życie i możliwość pracy.

Sytuacja gospodarcza państw Maghrebu nie napawa optymizmem. Wzrost gospodarczy Tunezji i Maroka w 2012 r. wyniósł odpowiednio 3,6\% i 2,7\%, państwa walczą z wysokim bezrobociem: w 2012 r. stopa bezrobocia w Tunezji wynosiła 16,7\%, a w Maroku 9\%. Wśród ludzi młodych bezrobocie pozostaje większe i sięga 17\% w Maroku i 42\% w Tunezji (2011 r. $)^{44}$. Oba kraje borykają się z wieloma problemami gospodarczymi, jak niska konkurencyjność gospodarek, spadająca pro-

${ }^{43}$ M. Ottaway, Morocco: Can the Third Way Succeed?, „Commentary” July 31, 2012, http://carnegieendowment.org/2012/07/31/morocco-can-third-way-succeed/d3op [dostęp 25.10.2012].

44 Do Tunezji wracają obywatele pracujący dotychczas w Libii; Deauville Partnership Ministerial Meeting, April 20, 2012, Washington, D.C., Middle East and North Africa: Economic Outlook and Key Challenges, IMF, http://www.imf.org/external/region/mcd/deauville/note042012.pdf [dostęp 25.10.2012]. 
duktywność, zadłużenie zagraniczne i wewnętrzne, korupcja, głębokie zróżnicowanie społeczne i regionów, a także niewydolność systemów opieki społecznej i braki mieszkaniowe. Wszystkie te czynniki doprowadziły do wzrostu niezadowolenia społecznego i - w konsekwencji - zwycięstwa wyborczego islamistów.

Programy gospodarcze Ennahdy i PJD były niemal identyczne, taki sam był nawet przewidywany wzrost gospodarczy $(7 \%)$. Obie partie zamierzały skupić się na walce z korupcją i bezrobociem, poprawie konkurencyjności gospodarek oraz wsparciu inwestycji, zarówno krajowych, jak i zagranicznych. Maroko chce rozwijać sektor małych i średnich przedsiębiorstw, dla których zarezerwowanych będzie przynajmniej 30\% projektów publicznych. Rząd planuje promocję samozatrudnienia i lepszy dostęp do pożyczek, chce także usprawnić i uszczelnić system podatkowy, obniżając podatki dla wszystkich grup podatników, a także dużych przedsiębiorstw ${ }^{45}$. Ani Ennahda, ani PJD nie planują renacjonalizacji czy zatrzymania procesu prywatyzacji, którego wolne tempo nie budzi ich zastrzeżeń. Właściciele sprywatyzowanych przedsiębiorstw prawdopodobnie nie muszą się więc obawiać o swoją własność. Nie należy się również spodziewać nacjonalizacji przedsiębiorstw państwowych.

Partie islamskie deklarują postawienie człowieka w centrum przemian gospodarczych. Od tej pory proces rozwoju gospodarczego ma prowadzić przede wszystkim do większej sprawiedliwości społecznej i równego podziału dóbr. R. Ghannouchi chciałby, by Tunezja stała się demokracją socjalną, na wzór Szwecji, gdzie gospodarka będzie zdominowana przez wartości społeczne, a nie zasady wolnego rynku ${ }^{46}$. Wyrównanie różnic społecznych ma nastąpić poprzez restrukturyzację wydatków publicznych, aby uczynić pomoc bardziej wydajną oraz by trafiała do najbardziej potrzebujących. Aby odciążyć budżet, chcą zmiany polityki podatkowej: likwidacji niektórych ulg podatkowych i wprowadzenia podatku progresywnego. Partie proponowały wprowadzenie zasad islamskich do systemu bankowego, ale obok tradycyjnych systemów finansowych, co nie zostało dobrze przyjęte przez inwestorów. Sukces zmian ma zapewnić właściwe podejście - zaangażowanie w politykę ludzi posługujących się wartościami islamu (uczciwych), nieskalanych korupcją.

W pierwszej połowie 2012 r. rząd tunezyjski przedstawił kompleksowy program rozwoju gospodarczego na kolejnych 5 lat. Ennahda skupiła się na tworzeniu nowych miejsc pracy, stawiając na pobudzanie wzrostu gospodarczego poprzez inwestycje międzynarodowe i krajowe. Rząd tunezyjski zaplanował działania na trzech

45 Édition no. 3667 du 2011/11/30, Législatives 2011. Economie: Ce que propose le PJD, http://www.leconomiste.com/article/889122-legislatives-2011breconomie-ce-que-propose-le-pjd [dostęp 25.10.2012].

${ }^{46}$ I. Saif, Muhammad Abu Rumman, The Economic Agenda of the Islamist Parties, May 2012, the Carnegie Papers, s. 6, http://carnegieendowment.org/2012/05/29/economic-agenda-of-islamist-parties/b0fh [dostęp 28.09.2012]. 
płaszczyznach: reform politycznych (walka z korupcją, przyjęcie zasad dobrego zarządzania i przejrzystości, niezawisłe sądy), reform regulacji prawnych (nowy kodeks inwestycyjny, prawo zamówień publicznych, prawo transportowe etc.) oraz rozwoju infrastruktury (rozbudowa sieci dróg i autostrad, sieci energetycznej etc.). Działania mają być skierowane na rozwój uboższych regionów wewnętrznych. W związku z faktem, że pierwsze efekty działań pojawią się najwcześniej pod koniec 2013 r., rząd uruchomi specjalne programy aktywizacji tymczasowej na najbliższe 2 lata. Są to projekty zatrudnienia około 100 tys. osób na kontraktach czasowych, szkolenia zawodowe dla absolwentów uczelni pomagające im lepiej dostosować się do rynku pracy oraz budowa 30 tys. domów socjalnych ${ }^{47}$.

W świetle przedstawionych planów ani Maroko, ani Tunezja nie mogą pozwolić sobie na dalsze zmniejszenie przychodów z turystyki, będącej kluczowym sektorem ich gospodarek. Sektor turystyczny już odniósł duże straty w związku z niepewną sytuacją polityczną w regionie. Nie pomogły także wypowiedzi członków Ennahdy, zapowiadające wprowadzenie ograniczeń postulowanych przez ugrupowania salafickie (m.in. nakazu noszenia zakrywających całe ciało kostiumów kąpielowych, zakazu picia alkoholu). Takie ograniczenia z całą pewnością zniechęciłyby do przyjazdu Europejczyków, a tym samym zmniejszyłyby wpływy do budżetu. Utrzymanie dotychczasowego status quo w turystyce obiecał ówczesny premier Tunezji Hamadi Jebali $^{48}$. Także PJD zobowiązała się nie wprowadzać regulacji zgodnych z szariatem.

Dużym utrudnieniem w realizacji planów gospodarczych może być fakt, że partie islamskie nie posiadają dostępu do czynników materialnych ${ }^{49}$ : dużych przedsiębiorstw o znaczeniu międzynarodowym, jak rafinerie czy kopalnie. Te wciąż pozostają własnością przedstawicieli dawnej władzy, którzy ani myślą dzielić się profitami z niegdysiejszą opozycją. Partie rządzące mają jednak dostęp do przedsiębiorstw państwowych, z czego korzystają, obsadzając swoimi ludźmi kluczowe stanowiska (Ennahda). Wciąż jednak istotne dla gospodarek państw arabskich podmioty pozostają poza zasięgiem wpływu grup islamskich. Ani Maroko, ani Tunezja nie posiadają złóż surowców energetycznych, które ułatwiałyby proces transformacji, dlatego koszty reform będą wyższe.

${ }^{47}$ L. Achy, Tunisia's Economic Challenges, The Carnegie Papers, Carnegie Middle East Center, December 2011, http://carniegieedowment.org/files/tunisia_economy.pdf

48 R. Spencer, Tunisia's victorious Islamists vow to uphold country's liberal laws, October 26, 2011, http://www.telegraph.co.uk/news/worldnews/africaandindianocean/tunisia/8851054/Tunisias-victorious-Islamists-vow-to-uphold-countrys-liberal-laws.html [dostęp 1.10.2012].

49 Dotychczas partie utrzymywały się z darowizn społecznych. 
O ile plany gospodarcze obu partii są dość ambitne, zachodzą poważne obawy, czy mogą w ogóle być zrealizowane. Ani PJD, ani Ennahda nie mają doświadczenia w rządzeniu, zwłaszcza w sytuacji kryzysu. Wprowadzenie wszystkich pomysłów w życie może okazać się procesem bolesnym, narażającym na utratę poparcia opinii publicznej. Z kolei brak działań może przyczynić się do upadku partii islamskich, równie spektakularnego, jak niedawne zwycięstwo wyborcze. Poza tym nieznane są źródła finansowania projektów. Wprawdzie Ennahda twierdzi, że będą one finansowane ze sprzedaży dóbr skonfiskowanych byłemu prezydentowi Ben Alemu, rząd tunezyjski liczy także na granty od krajów arabskich i UE. Sprawę dodatkowo komplikuje wciąż niestabilna sytuacja wewnętrzna Tunezji.

\section{Islam i zagranica}

Przejęcie władzy w Afryce Północnej przez partie islamskie zostało przyjęte z dużym zaniepokojeniem przez świat zachodni. Oto u bram Europy laickie rządy zastąpione zostały przez dotychczas marginalizowane ugrupowania religijne o bliżej nieznanych celach i zamiarach.

Ugrupowania islamskie nie mają doświadczenia we współpracy zagranicznej. Przed wybuchem rewolucji obie partie pozostawały w politycznej izolacji zarówno we własnym kraju, jak i za granicą. Kontakty międzynarodowe utrzymywały jedynie z innymi partiami islamskimi, zwłaszcza z egipskim Bractwem Muzułmańskim. Państwa zachodnie ignorowały istnienie partii islamskich, licząc na to, że zostaną one utrzymane $z$ dala od władzy przez rządy swoich krajów.

Oba państwa Maghrebu były tradycyjnie otwarte na współpracę z Zachodem. Rządy europejskie wielokrotnie udzielały wsparcia politycznego, gospodarczego i finansowego władzom Maroka i Tunezji. Szczególne więzi łączą państwa Maghrebu z dawną metropolią: Francją, która niejednokrotnie udowodniła szczególny charakter łączących kraje stosunków dwustronnych. Wydaje się, że także obecnie oba państwa mogą liczyć na pomoc europejskich sąsiadów, choć państwa zachodnie z dużą rezerwą podchodzą do nowych religijnych władz Maroka i Tunezji. W stolicach europejskich wciąż żywe są wspomnienia zamachów z września 2001 r. oraz bomb z Madrytu i Londynu, stąd kontrola islamskich odłamów radykalnych i trzymanie ich z dala od władzy pozostaje warunkiem sine qua non owocnej współpracy.

Ze strony Maghrebu płyną zapewnienia o ciągłości współpracy i partnerstwa z Unią Europejską. Wydaje się, że nie należy spodziewać się ograniczenia kontaktów handlowych, jako że Europa pozostaje ich najważniejszym partnerem gospodarczym. 
Tunezja zaproszenie do współpracy kieruje nie tylko do firm europejskich, ale także do przedsiębiorstw z krajów ościennych i rejonu Zatoki Perskiej ${ }^{50}$.

Partie islamskie nie rozwijają współpracy horyzontalnej pomiędzy sobą. Na spotkaniu w Carnegie Endowment for International Peace w Waszyngtonie w maju 2012 r. dyskutowano o ostatnich zmianach w Afryce Północnej. W spotkaniu uczestniczyły partie islamskie z Maroka (PJD), Tunezji (Ennahda), Egiptu, Libii oraz Jordanii. Jak skomentowała Marina Ottaway, „partie islamskie wydają sie być rzeczywiście partiami narodowymi. Wydaje się, że nie istnieje coś, co można byłoby nazwać <<Islamską Międzynarodówką〉>, do której wszystkie by należały. Partie chyba nawet nie utrzymują kontaktu między sobą. Na konferencji mieliśmy wrażenie, że więcej my wiemy o nich niż oni o sobie nawzajem" ${ }^{1}$. Jak się okazuje, partie islamskie mają podobne problemy (gospodarcze, polityczne i społeczne), nie konsultują jednak między sobą możliwych rozwiązań, nie wymieniają się doświadczeniami. Być może jest na to jeszcze zbyt wcześnie.

\section{Wnioski}

Rewolucja arabska, zwana też Arabską Wiosną, oddała ster rządów w Maghrebie partiom umiarkowanie islamskim: Ennahdzie i PJD. Obie partie rozpoczęły proces reform, niezbędny wobec drążących je problemów gospodarczych, politycznych i społecznych, którego efekty będą znane najwcześniej za kilka lat.

Pewnym utrudnieniem jest charakter religijny Ennahdy oraz PJD, narzucający im ograniczenia polityczne i nakazy oraz wzbudzający nieufność w części społeczeństw. Obie partie wprawdzie starają się funkcjonować jako normalne partie polityczne, nie jest to jednak zadanie łatwe. Nie wszyscy działacze zaakceptowali zmiany programowe obu partii i obecnie przyjęty bardziej świecki kierunek rozwoju, część $\mathrm{z}$ nich nadal sympatyzuje $\mathrm{z}$ ugrupowaniami o charakterze radykalnym. Zmiany programu mogą także nie zrozumieć lub nie zaakceptować wyborcy obu partii, którzy przecież głosowali na ugrupowania religijne, wprawdzie o charakterze umiarkowanym, ale wciąż religijne. Korekta kierunku, która w konsekwencji doprowadziła do

${ }^{50}$ M. al Makki Ahmad, Tunisian PM Ghannouchi: „Syrian People Will Soon Achieve Victory”, January 17, 2012, http://www.al-monitor.com/pulse/politics/2012/01/al-ghannouchi-the-syrian-people.html [dostęp 28.09.2012].

${ }^{51}$ M. Ottaway, M. Muasher, Islamist Parties in Power: A Work in Progress, „Commentary” May 23, 2012, http://carnegieendowment.org/2012/05/23/islamist-parties-in-power-work-in-progress/aw7x [dostęp 25.10.2012]. 
konfliktu z innymi ugrupowaniami o charakterze religijnym i współpracy z partiami świeckimi, może wywołać zrozumiałą niechęć i odwrócenie sympatii politycznych, szczególnie niebezpieczne w świetle zbliżających się kolejnych wyborów parlamentarnych i prezydenckich w Tunezji. W rządzeniu nie pomagają również radykalne ugrupowania religijne, wzniecające nowe zarzewia konfliktów. Dlatego też Ennahda może być zmuszona do pewnych ustępstw w stosunku do islamistów. Dopóki konstytucja nie zostanie uchwalona, wszelkie zmiany są wciąż możliwe, czego obawiają się przeciwnicy islamizacji kraju.

Wydaje się, że najlepszym środkiem na neutralizację realnego lub wyimaginowanego zagrożenia ze strony islamistów jest większe zaangażowanie partii religijnych w funkcjonowanie systemu politycznego krajów Maghrebu oraz włączenie do działań międzynarodowych. Odpowiedzialność polityczna pomoże zmniejszyć dotychczasową nieprzewidywalność partii islamskich i jednocześnie utrudnić powtórzenie sukcesu wyborczego. Już nie wystarczą deklaracje i plany, wyborcy będą oczekiwali konkretnych działań, zwłaszcza w sferze socjalnej. Ennahda i PJD muszą więc szybko doprowadzić do poprawy sytuacji gospodarczej Maroka i Tunezji, przede wszystkim przyspieszenia wzrostu gospodarczego i zwiększenia liczby miejsc pracy. Rozbudziły duże oczekiwania społeczne, którym trudno będzie sprostać. A bez wzrostu gospodarczego sukces polityczny jest niezwykle wątpliwy.

\section{Uwagi końcowe}

Trwające w sumie ponad dwa lata prace Tunezyjskiego Zgromadzenia Konstytucyjnego znalazły swój finał 26 stycznia 2014 r., kiedy zakończono głosowanie nad nową ustawą zasadniczą Tunezji. W rezultacie ogólnonarodowej dyskusji przyjęte zostały kompromisowe rozwiązania prawne, co daje nadzieję na ostateczne wyciszenie konfliktu wewnętrznego między islamistami a zwolennikami świeckiego państwa i przyczyni się do stabilizacji sytuacji wewnętrznej w kraju. Analiza regulacji zawartych w nowej ustawie zasadniczej będzie przedmiotem opracowania, które pojawi się w kolejnym numerze publikacji. 


\section{Tunisia and Morocco: different faces of Arab Spring}

Political changes in Northern Africa, known as the Arab Spring, allowed religious parties to take over the power. In the paper I analyzed political developments in Tunisia and Morocco in the past two years. Both countries have accepted reform agendas though their implementation brought about different results. In Tunisia the changes were very volatile, deeply interfering with all aspects of public and private spheres. In Morocco, on the opposite, the process was much more gentle, overseen in all aspects by king Mohamed VI. The fact that ruling political parties have religious roots has influenced the process of reforms and caused serious anxiety. The complexity of the economic, social, and political challenges in both countries hinders the reform process. The tensions between two ways of development (religious and secular) cause controversy and uncertainty which are the subject of this paper.

Keywords: Morocco, Tunisia, Maghreb, Arab Spring, Islam, reforms

\section{La Tunisie et le Maroc: les différentes facettes du «printemps arabe »}

Les changements politiques en Afrique du Nord - le " printemps arabe » - ont permis aux partis religieux de prendre le pouvoir. Lauteur analyse la situation politique en Tunisie et au Maroc au cours des deux dernières années. Les deux pays avaient accepté les programmes de réforme, mais leur mise en œuvre a conduit à des résultats différents. En Tunisie, les changements observés ont été très volatils; ils ont profondément affecté tous les aspects de la vie publique et privée. Au Maroc, au contraire, le processus a été beaucoup plus doux, comme il a été supervisé à tous les aspects par le roi Mohammed VI. Le fait que les partis politiques au pouvoir ont des racines religieuses a influencé le processus de réformes et causé de graves inquiétudes. La complexité des défis économiques, sociaux et politiques dans ces deux pays entrave le processus de réforme. Les tensions entre les deux voies de développement - religieuse et laïque - provoquent la controverse et l'incertitude qui font l'objet d'une analyse approfondie dans cet article.

Mots-clés: le Maroc, la Tunisie, le Maghreb, le «printemps arabe », l'islam, les réformes 


\section{Тунис и Марокко. Лица арабской весны}

Политические изменения в Северной Африке, известные как арабская весна и которые охватили большинство стран Магриба и Машрика, в результате привели к захвату власти религиозными группами. Статья включает анализ политических изменений, произошедших за последние два года в Тунисе и Марокко. В обеих странах были предприняты усилия по реформированию, но они отличались по характеру и достигнутым результатам. В Тунисе изменения проходили быстро, охватывая все сферы общественной и частной жизни и глубоко нарушая установленный общественный порядок. В Марокко этот процесс намного тише, почти незаметен, а за его ходом и окончательными результатами наблюдает король Мохаммед VI. Важную роль в процессе реформирования играет религиозный характер правящих партий, который, в большей или меньшей степени, сказывается на направлении и степени изменений, а также реакции населения Туниса и Марокко, с опасением воспринимающего растущие влияние исламистов. Разнообразие экономических, политических и социальных проблем в обеих странах не способствует процессу реформ, последствия которых будут видны через несколько лет. Предметом данного исследования является борьба между двумя направлениями развития (религиозным и светским), вызывающая большое волнение и неопределенность связанную с последствиями политических преобразований. 